\title{
Train as a Semantic Space in Russian Culture of the $19^{\text {th }}-20^{\text {th }}$ Centuries
}

\author{
Diana V. Mosova, Natalia P. Dmitrenko, Olga N. Kolchina, \\ Svetlana N. Averkina \& Anzhelika G. Kalinina \\ Department of Russian Philology, Foreign Literature and Intercultural \\ Communication, Linguistics University of Nizhny Novgorod, Nizhny \\ Novgorod, Russian Federation. \\ E-mail: s.averkina6o33@uohk.com.cn
}

\begin{abstract}
The railway station is the most important chronotope of the $20^{\text {th }}$ century. In times of industrialisation, economic development, military confrontation between major powers, the images of a steam locomotive, locomotive, and train met in a large body of literary and journalistic texts. The study of the railway discourse is based on complex historical and semiotic meanings, which allow concluding about the properties of the Russian cultural world, studying it from a new perspective. In the process of the research, the methods of the theoretical level were used: the study and generalisation of scientific works, analysis and synthesis, induction and deduction. The authors conducted a logical analysis of the collected material, developed new categories of the image of a train as a "fiery demon", "a locomotive of progress", "house on wheels". Semantic models of perception of the train as a cultural space were interpreted. A discursive analysis of ideas that influenced the semantic part of the concept of "railroad" in Russian culture was conducted. It was concluded that the image of a train in literary creation has a dual character. Already at the stage of the construction of the railway, an infernal model of its interpretation as a "serpent train/dragon" was formed, capable of destroying all living things and taking them to the kingdom of death. At the same time, there are examples of a different type of interpretation of the image of a train. Some researchers insist on its connection with the archetype of "mother", the idea of movement in a circle, return. In the post-Soviet space, the image of a train has not lost its significance. It is still assimilated by mass culture, it enters into everyday life, without losing its ambivalent character.
\end{abstract}

Keywords: cultural and semiotic space, mythopoetics, archetype, semantic model

\section{Introduction}

Problems of space exploration, opening new horizons, expanding ideas about speed and possibilities of movement are traditionally fundamental in the experience of cultural understanding of reality. From medieval mythologism and symbolism, literature has come a long way to a realistic depiction of the technical and intellectual capabilities of a person, without forgetting, however, about the primordial toposes that form artistic thinking: rivers, oceans, land, sky, forests, mountains. Tales of pilgrimages and knights' campaigns have replaced $18^{\text {th }}$ century nautical novels,

(c) AesthetixMS 2021. This Open Access article is published under a Creative Commons Attribution Non-Commercial 4.0 International License (http://creativecommons.org/licenses/by-nc/4.o/), which permits non-commercial re-use, distribution, and reproduction in any medium, provided the original work is properly cited. For citation use the DOI. For commercial re-use, please contact editor@rupkatha.com. 
sentimental travels of pre-romanticism, tales of exotic lands of the early $19^{\text {th }}$ century, and bitter tales of poverty and deprivation of the period of documentary sketches of realism. Undoubtedly, such a fact as the creation of the railway was actively rethought by writers, found expression in the works of authors who became contemporaries of this grandiose event. For Russia, this topic remains relevant to this day.

The opening of the first publicly available state-owned Nikolaev railway (1851) became for Russian society the most important event not only of a political, but also of a cultural and historical scale. It can be argued that there has been a shift in the understanding of the fundamental philosophical categories, a new era has begun, marked by contradictory trends. The ability to travel on an "iron horse" radically changed the idea of speed, movement, space, experience of time and opened up new opportunities for the country's economic and spiritual growth. It seemed to the proponents of technological progress that humanity had won another great victory over nature. Sceptics thought differently. Russia at that time was a huge country, with a capricious climate, vast expanses, bad roads and, for the most part, an illiterate population. The construction of a system of railway communications seemed to be a costly, long-term process, perceived by the common people as something that was breaking the foundations, violating the established way of life.

This duality is firmly rooted in the history of the perception of the image of a train in Russian culture. At each difficult turn in history, it acquired new rings of the cultural memory, which found expression in classical literature (Dostoevsky, 2012; Tolstoy, 2013). Particular attention should be paid to the perception of the railway in photography and cinematography, from the first stages of its formation to the last significant film works. It is no coincidence that many Russian literary critics, cultural studies and philosophers paid attention to this problem. Studies of foreign scientists have also long and firmly entered the scientific use, in particular, M. Foucault's (2002) theory of the role of machines and mechanisms in the establishment of dictatorships, the idea of technical means as "prostheses" of power, reflections on the dangerous turns of technisation that struck modern society.

\section{Materials and methods}

On the stated research topic, there is a significant scientific groundwork (Komagina, 2011; Nepomnyashikh, 2012; Lesovichenko \& Maltseva 2014), which, on the one hand, complicates, on the other hand, simplifies the choice of strategies and methods of working with the material. Scientists have thoroughly studied the history of the development of railway communication, described the main stages in the formation of the artistic image of a steam locomotive and a train, studied the archetypal features of this image. Based on the results presented by other literary scholars, it is possible to avoid repeating some general points and focus on new turns of the "scientific plot": creating an ambivalent model of the image of a train as a "fiery demon" and as a "locomotive of progress", "house on wheels". The main principle of working with the material was a broad view of the problem of the reception of the image of a railway, starting from the first mention of it, ending with modern examples. This made it possible to talk about the genesis of the process of perception and its polarisation.

The research focuses on both the documents of the era, statements of eyewitnesses, and the precedent texts of writers from different eras. This approach can be called cultural-historical, understanding it more broadly than at the early stage of the formation of the method. It seems that it is the phenomenon of precedence that makes it possible to single out from a large body of materials those texts (in the broad sense of the word) that are capable of representing the main discourses that have developed over the almost two hundred year period of the existence of the 
railway. According to the competent opinion of Yu.N. Karaulov (2007) precedent are "tests/statements" that are significant not so much for an individual or a group of persons, as those that are of a supra-personal nature and are known to a wide range of people. At the same time, the mention of individual names, texts, lines from songs and fragments from films connects the communication participants to a wide cultural context, which continues to form to this day. This approach once again emphasises the relevance of the chosen topic.

At the same time, the article touches upon the problem of interpretation of semantic models of perception of a train as a cultural space. In this part of the study, the most important are works on the functioning of archetypes in literature and works on semiotics (Lotman, 2015; Jung ,2016; Shchepanovskaya, 2012). The perception of a particular artistic model can take place according to several scenarios, from full acceptance to denial. The mechanisms and nature of reception depend on the historical era, cultural context and the individual experience of a recipient. Analysis of different forms of perception of cultural phenomena helps to deeper and broader interpret the picture of the world that is taking shape in certain periods of development of Russian and Soviet society. Since not only artistic tests were in the focus of the work, the works of scientists devoted to the issues of translation from one language of culture into others, the synthesis of arts (Gillespie, 2017; Gural, 2015; Leontieva, 2007). Finally, an attempt is made to conduct a discursive analysis of the basic concepts involved in the formation of the "railway" semantic field in the domestic culture, which has its own historical and national characteristics (Foucault, 2002; Clark, 200o; Kosovsky, 1991).

\section{Result and discussion}

Actually, the authors would like to start the research part with a small historical background. The official inauguration of the "Petersburg - Tsarskoe Selo" route, intended for members of the imperial family, took place on October 30, 1837, but reflections on the development of land rail transport began during the reign of Paul I. Realising the complexity of the task, officials tended to support the river and maritime shipping. So, analysing the situation in the Russian Empire, Lieutenant General of the Corps of Railway Engineers M.G. Destrem (2013) wrote: "... the benefits of canals over cast-iron roads have the greatest degree of superiority in Russia". This position remained official for a long time. The Russian Empire lagged behind its European neighbours in the field of land transport, which had adverse consequences for the country's political life. The lack of good roads between central Russia and the Black Sea influenced the defeat in the Crimean War of 1853-1856 and prevented control over remote regions of the country.

The construction of railways caused controversy among people far from science and politics. What this innovation foreshadows are the paths connecting remote settlements, powerful tractors, steam locomotives, inexorably moving through specially created spaces, "freed from the forest, levelled, smelling of something alien and frightening" (Komagina, 2011). It is no coincidence that already in the middle of the $19^{\text {th }}$ century the image of a train acquired infernal features associated with mythologems of a dangerous path, a symbolic descent into Hell, tests by fire, widely represented in folklore and oral creativity (Propp, 2014). In the popular mind, a steam locomotive, puffing, emitting clouds of steam, interacted with the fabulous image of a serpent/dragon. Recall the story of the wanderer Feklusha, given in the play by A.N. Ostrovsky's (2016) "The Thunderstorm", who satirically recreated in his dramas the pictures of the dark kingdom and the total ignorance of the inhabitants of the Russian hinterland: "Why, mother Marfa Ignatievna, they began to harness the fiery serpent: everything, you see, for the sake of speed". 
The disruption of the usual rhythm of human life was tirelessly criticised by representatives of the church. In this regard, the judgment of Bishop Nikanor seems extremely interesting and even witty, warning about "the harm of railways, steam and, in general, about the dangers of moving too quickly through life": "fast modern communications destroy incredibly the speed with which we rush to no one knows where, as if not into the abyss. Excessive speed is always and everywhere dangerous", - an entry of 1886 (Leontieva, 2007). Today, in the era of air transport, when the Internet allows virtually overcoming all kinds of borders and distances, this idea sounds especially relevant (Gural and others, 2015). An appeal to Russian literature of the second half of the $19^{\text {th }}-$ early $2 \mathrm{O}^{\text {th }}$ centuries provides rich material for examples and reflections on a given topic. One of the most famous examples is the poem by I.F. Annensky (2013) "Winter Train". The poet portrays a steam locomotive as a "fire-breathing dragon", the carriages as "coffins"; an iron soulless machine spews out the energy of death, capable of destroying a weak person:

The dumb black of snows

Are burned by two eyes from fog

And smoke is flying

As golden fire of a fountain.

I know - fire-breathing dragon

All covered with fluffy snow

Now breaks with a rebellious run

The sleep of an enchanted far.

With him, tired slaves,

Doomed to the cold pit,

Heavy coffins are moving

Creaking and clanking with chains,

While with a broken lantern

Half dimmed

In the midst of a nightmare of doom and slumber

Midnight passes through the wagons...

Often the struggle with the "serpent train" takes on the character of a national confrontation: "The Russian people have endured enough, / have endured this railroad too - / Will endure everything that the Lord will send!", the poem "Railroad" (Nekrasov, 2015). Imperial claims are opposed to the long-suffering of the Russian people. This idea is also heard in a large body of texts dedicated to the sacrifices made during the construction of the Baikal-Amur Mainline (BAM). The demonisation of the image of a steam locomotive reaches its absolute climax in the "March of Railwaymen", written in fatal for the history of the USSR 1937, by M. Dunaevsky (2003). This is a kind of anthem of the era, in which the concept of a "leader-machinist", who runs the country like an obstinate locomotive, sounds like a frightening refrain: "Beloved Stalin is a machinist of the great Soviet country!". In recent years, many interesting works have appeared that reveal additional dimensions of the problem under consideration.

For example, the article "Railway as a complex of motives in Russian lyrics and epics" is devoted to the negative perception of the "road on bones" in Russian lyric poetry and epics of the $19^{\text {th }}$ century, in which the author examines the system of motives associated with the realisation of the idea of the chthonic nature of the phenomenon: "the inevitability of death/catastrophe on the railroad", "destruction of nature and the patriarchal way of life", "trains as a generalised embodiment of the evil of technical progress" (Nepomnyashikh, 2012). The image of a train is considered in the article as the realisation of several metaphors: the railway as an excessive speed 
of movement through life (the iron is compared with the soulless); railway - road on bones/road to death/to hell/death path of technical progress to disaster; a way of overcoming, an optimistic movement forward, to a new, better in the life of a person and society. Railroad as a utopia; a train is a guide to other worlds (literary, surreal). N.A. Nepomnyashikh (2012) cites a remarkable comparison of the railway with the world wide web, ready to envelop the entire globe, to establish a new power without borders. This image was first mentioned by the Russian diplomat, philosopher K.N. Leontieva (2007): "It is dangerous, lest the earth soon begins to resemble the world wide web, that entangles the entire globe, in which only an emaciated omnivorous person swims, like a hungry spider, who does not know who and what to devour, since he himself devoured, beat, tore apart all life on the surface of the entire earth. Do these railway lines look like the threads of the world wide web?". The philosopher paints an apocalyptic picture, warning against excessive enthusiasm for technical progress.

Separately, it is worth dwelling on the work of the great prose writers of the $19^{\text {th }}$ century F.M. Dostoevsky (2012) and L.N. Tolstoy (2013) and especially on modern film adaptations of their works, which have gained exceptional popularity in recent years. Meetings, partings, conversation on a train - motives literally permeate the creativity of realist writers; not only Russian, but also European. Analyse a few vivid and important for understanding ways of symbolising the image under study: the description of an incident on the railway at the beginning of the novel "Anna Karenina", the exposition of the novel "The Idiot" - the meeting of the main characters in a thirdclass carriage "on a chilly November morning" - and confession of Vasily Pozdnyshev, returning home after ten years of hard labour with random passengers in the story "The Kreutzer Sonata" (Tolstoy, 2012).

All examples can be combined according to one criterion: they describe dialogues devoted to acute social issues - inequality of people before the law, general decline in morals, wealth/poverty, treachery of the "fathers of the family", female emancipation. They should be interpreted taking into account an important semantic framework - "conversation on a train". Lines are pronounced for everyone and for no one individually. The fellow travellers know almost nothing about each other, which makes the conversation dramatic, somewhat theatrical. The very description given in the novels seems to be alive and multilevel. But such scenes require "presentation", "visualisation", which can be realised in film adaptations of works (Gillespie and others, 2017). With the help of techniques typical for cinematography, directors offer interpretation, reading of the text in cinematic images, which "are linked into a new cinematic narration, a cinematic story" (Lotman, 2015).

In the 1967 film adaptation of Anna Karenina directed by A. Zorkha and T. Samoilova, the image of the train is multifaceted. The social context is important here, which is revealed in the first episode of the accidental death of a railway employee. The author of the monograph "F.M. Dostoevsky and L.N. Tolstoy (novels of the 60-70s)" K.I. Megaeva (2002) notes the pattern of this tragedy: "Crashes and accidents on the railways were widespread and caused fear of the iron pot ... The road is almost deadly." The act of Karenina, about which one can argue for a long time, is revealed in the film not only as a result of a neurotic attack but also as a fact of social life. The tragedy of Anna's death is interpreted as an awareness of general chaos, brings back to the title phrase of the novel "everything got mixed up in the Oblonskys' house", just as everything outside it. The train appears as a soulless colossus, the hammer of fate, the embodiment of universal indifference.

One of the brightest films of the 2ooos also deserves great attention - the series "The Idiot" directed by V. Bortko and E. Mironov (Prince Myshkin) and V. Mashkov (Rogozhin) in the lead 
roles. A feature of this film adaptation was the exact adherence to the original text. An important role was played by the attraction of talented actors, musical accompaniment, thoughtful production (the producer was the famous director V. Todorovsky). The film opens with a scene of the meeting of the main characters on the train. Myshkin and Rogozhin are sitting opposite each other; the scene is built on contrast. The image of the prince is interpreted from a Christian perspective: he is a "stranger", a messenger of strange changes, devoid of passions, greed, and finally, an unhealthy person. Myshkin enters the "new prophet" into "new Jerusalem" (Petersburg) on a "new donkey" (a steam locomotive). And, like Jesus, he sacrifices himself for the sake of the world, which even after a millennium is not ready to understand him. The train is a powerful and semantic magnet that helps to "tie" a complex plot, which will resolve the collapse of the hopes of the protagonist and his ideological counterparts.

The key metaphor of Tolstoy's story “The Kreutzer Sonata” - a person feeling lost and lonely - is taken up by director A. Trofimov in the 1987 film. In this film, the train embodies human passions - bodily and spiritual, capable of crushing an individual. It is no coincidence that in the scene with the young hero's visit to the brothel, the crowd of intoxicated orgy participants "collides" with an imaginary train - a kind of movie quotation (one of the first short films "Arrival of a Train at La Ciotat Station”, 1895). The director's task was to convey the fear inspired by the sexual trauma of a young man entering adulthood. There is a complex autobiographical reference here, which should also be spoken of on purpose. There are frank memories of Tolstoy about his first visit to a brothel, where he was dragged by the brothers. The writer admits that after the first bitter experience he sat down by the bed of the surprised woman and began to cry (Megaeva, 2002).

In a confession to a casual fellow traveller, Pozdnyshev constantly returns to the experience of youth. Forever, lust in his mind is combined with bitterness and emptiness. In the film adaptation of the story, this motif is introduced with the help of a close-up movement of the wheels of a steam locomotive, followed by a shot with the release of steam, accompanied by a whistle reminiscent of the howl of a contented animal. The image of a steam locomotive in the texts of F.M. Dostoevsky and L.N. Tolstoy closely merges with the image of death. This model has obvious mythopoetic foundations: it is rooted not only in the Slavic folklore tradition, but also fits into the context of the common European cultural memory (Gillespie \& Gural, 2016). In this regard, research in the field of psychoanalysis, based on the study of primary models of symbolisation, seems to be interesting. In his early work “The Interpretation of Dreams", reflecting on the ways of expressing anxiety, S. Freud (2015) notes that departure is a sublimated embodiment of the image of death; therefore, "dreams of being late for the train ... contain consolation in the fear experienced in a dream: the fear of dying". K.G. Jung (2016) in his book "Psychology and Poetic Creativity" develops this idea, interpreting the plots of man-made disasters as a modernised version of the mythical combat with the dragon. The archetype of death is realised, in his opinion, in the metaphors of the path, movement, transformation.

In all known myths, the Kingdom of Death is not only an invisible but also an unknown goal, a country from which one cannot return, a one-way journey. However, in almost all mythological systems some heroes visited the underworld and returned from it transformed, having learned the prophecies. Initiation by death is part of life itself, a step from "inevitability to freedom" (Heidegger6 2013). The test becomes the main one in this process. In some beliefs, snakes are not allowed into the kingdom of darkness (Lithuanian mythology - the Vizuna snake, Indian - the Vritra snake and others). The motive of fighting the serpent expresses the idea of heroism in opposition to death. However, the days of epic confrontations are long gone. The modern world 
can be described as non-heroic, rational, balanced. Death is viewed not so much in a mythological vein as in a scientific one.

Many experts in the field of thanatology warn about the negative consequences associated with the loss of the heroic symbolism of death: "The paradox is that, despite the development of medicine, death has ceased to be worthy, not to mention the fact that it has lost its high spiritual meaning by exposing for all to see its ugliness..." (Shchepanovskaya, 2012). A sign of a hurrying era was the train, later the plane, and in archaic times, the last journey took place on the leisurely waters in Charon's small boat. Perhaps, the crisis of the glorification of life is associated with the interest of modern culture in epochs of great upheavals and a new round of research into revolutionary aesthetics, the period of building communism, when the energy of feat was coupled with the movement of cars, steam locomotives, ships, and the idea of victory was associated with the speed, swiftness of the mechanism (Chemezov, 2015). The authors who worked in the era of the first years of building socialism actively exploited the positive potential of the train image. It is most explicitly expressed in the literature of socialist realism, in particular in such a variety as the production novel. One can argue about the artistic merits of these texts, but their cultural interest is obvious, as noted by many scholars dealing with the problem of the neo-mythologism of Soviet literature and the utopias of the era of pathos of transformations (Clark, 20oo; Kosovsky, 1991). The latest research of Russian literary scholars is devoted to the production novel. The dissertation of D.D. Zemskova (2016) "Soviet production novel: evolution and artistic features of the genre", in which the author finds signs of continuity and a complex system of axiologems referring to folklore and Christian contexts.

As an example, the authors cite a small fragment of the novel by the Soviet writer A.D. Kartsev "Magistral" dedicated to several generations of railway builders. This is a saga about the life of robbers, machinist workers, paving the way in the impassable parts of immense Russia in the taiga, steppe, on virgin lands. Generations of strong and young people are gripped by a common pathos of construction and transformation. The text of the novel amazes with its lyrical assertiveness and energy, in front of the eyes of the workers cities grow and disasters occur, for example, on the Tiligul wall. The heroine of the novel describes the purpose of her work in the brigade in the following way: "Somewhere there will be noise, the edge will stir from rapid movement, goods and bread and meat will flow in the carriages, books and pianos will appear where they were previously seen only by chance, electric bulbs will shine in shops and clubs, in new and old houses, there will be gardens in squares and new factories in wastelands overgrown with weeds, people move faster, it will become louder on the streets and in rooms, artists from big cities will come to the theatre, girls will dress up more carefully, old and young people will shave more often, and where well stood at a dirty intersection, a water pipe will run under the asphalt... (Kartsev, 1962).

The main metaphor for this passage is movement, rapid uncontrolled growth: "stir up, flow, fast movement". Everything appears in a transformed form, adjectives are used in a comparative degree: "faster (people move in), more caring, more often (they will shave)". In the future, the inhabitants of the steppe town will find everything "new" and certainly "big". And it is a train that will become the messenger of a wonderful life, and the highway built by human hands will give it the right direction. It should be mentioned that even earlier, long before the revolution and the Soviet era, in Russian poetry of the $19^{\text {th }}$ century, there were descriptions of a railway carriage as a cosy, protected space associated with children's perception of a long pleasant journey: "Frost and night over the snowy street / And here it is cosy and warm ...", - a poem by A.A. Fet (2010) "On the railway". The train was often referred to as a "motor home". 
The authors of the article "Mother archetype as the basis of railway images in literature and art" by A.M. Lesovichenko and E.A. Maltsev (2014) noted the possibility of interpreting the image of a carriage as space "which brings people together to the limit, since they inevitably fall into the zone of each other's life experience". Researchers prove that the image of a train goes back to the mother archetype, the realisation of which K.G. Jung sees in figures such as grandmother, stepmother, mother-in-law, goddesses, things that evoke piety or a sense of awe in humans, such as the church, city, country, land, forests and seas, the underworld and the moon, or just some subject, magic circle, monad. Thus, the etiological and traumatic influences that traditionally come from a mother, Jung divides into two groups: "those that correspond to the character traits and relationships inherent in the mother; and those that relate to traits only seemingly inherent in the mother, and which consist of more or less fantastic (i.e. archetypal) projections from the child's side" (Jung, 2016). This archetype is realised through "movement in a circle," meaning a conditional return to the mother, the source, and sometimes inevitable death.

The real sign that the phenomenon is being mastered by the culture, enter it, is its inclusion in the everyday consciousness. The train and especially the electric train entered the life of Soviet people and Russians. Love as the main theme of popular music also cannot do without railway transport: remember V. Makarov (2020) "Again the last train ran away from me", the song by A. Apina (2020): "He left on the night train, if only to light a cigarette, but all the matches are wet". All adversity is easily perceived. In the Soviet and early post-Soviet consciousness, the train takes on the image of a cute good friend, a cartoon locomotive, slowly trudging to a nearby station, knowing no competition or fuss. Russian rock has finally mastered the locomotive theme. The carriage, like the kitchen, has become a space of revelations. It seems that this shade of meaning will never leave Russian culture, which is characterised by spontaneous night-time confessions and morning regrets about them: "Carriage disputes are the last thing when there is nothing else to drink...” - A. Makarevich's (2020) song. In fact, the song of Grebenshchikov (2020) became the anthem of perestroika "This train is on fire / and we have nowhere else to rush...".

\section{Conclusion}

The "dual" image of the railway, bearing the features of creation and destruction, has become a symbol of the historical and cultural path of Russia. The semantic depth and openness of mass culture made it extremely attractive for study by domestic and even more foreign specialists in various fields of knowledge, and the new folklore that arose around the importance of the modern corporation of Russian railways in the life of Russia remains new little-studied material. It seems that an appeal to the topology of classical works of literature and products of mass culture makes it possible to expand the palette of perception of images that have long been included in everyday life, but have not lost their symbolic and morpho-poetic depth. Only a careful study of such important spheres for comprehending Russian culture as "the perception of space", the feeling of "space" characteristic of the Russian concept sphere, will make it possible to draw serious conclusions about the cultural world of Russia.

Interest in the chronotopes of Russian culture is not limited only to the railway. The image of a tram played a huge role in the formation of Russian literature. A metro remains a real "hero" of many contemporary texts. The poetry of flight is another turn of possible research, not to mention the fantastic literature devoted to the creation and study of parallel worlds in which there is much in common with this one. All this could constitute a further perspective of work on the problem of the "semantic load" of space in contemporary Russian culture.

\section{References}


Annensky, I.F. (2013). Winter Train: Selected Works. Moscow: Fiction.

Apina, A. (2020). Electric train. Retrieved from https://teksty-pesenok.ru/rus-alyona-apina/tekst-pesnielektrichka/1731821/

Chemezov, Ya.R. \& Gural, S.K. (2015). Difficulties in interpretation of situation-bound utterances by Russian EFL students. Procedia-Social and Behavioural Sciences, 200, 174-178.

Clark, K. (200o). The Stalinist myth of the "great family", In: Socialist Realist Canon: Collected Articles. St. Petersburg: Academic project. 72-96.

Destrem, M.G. (2013). Railway journal. Retrieved from https://read-this-text.blogspot.com/2013/5/blogpost_9244.html

Dostoevsky, F. (2012). Idiot. Moscow: Azbuka.

Dunaevsky, M. (2003). Railwaymen March: For unaccompanied voice. Moscow: Musyka.

Fet, A.A. (2010). Full composition of writings. Moscow: Belyi gorod.

Foucault, M. (2002). Intellectuals and power. Moscow: Praxis.

Freud, Z. (2015). Interpretation of dreams. Moscow: Azbuka.

Gillespie, D., Gural, S.K. \& Kim, A.A. (2017). Promotion of the Russian language into the Eurasian space through the culture and way of life of the peoples of Siberia. Language and Culture, 40, 8-19.

Gillespie, D.Ch. \& Gural, S.K. (2016). Film adaptation and cultural politics: the Russian approach to screening literature. Bulletin of Tomsk State University, 413, 52-57.

Grebenshchikov, B. (2020). The train is on fire. Retrieved from https://lyricstranslate.com/ru/BGrebenshchikov-POEZD-V-OGNE-lyrics.html

Gural, S.K., Boyko, S.A. \& Serova, T.S. (2015). Teaching literary translation on the basis of the literary text's cognitive discourse analysis. Procedia-Social and Behavioral Sciences, 200, 435-441.

Heidegger, M. (2013). Being and time. Moscow: Akademichesky Prospekt.

Jung, C.G. (2016). Archetype and symbol. Moscow: Canon + RPOI "Rehabilitation".

Karaulov, Yu.N. (2007). Russian Language and Language Personality. Moscow: LKI Publishing House.

Kartsev, A.D. (1962). Magistral. Moscow: Soviet Russia.

Komagina, S.G. (2011). The image of the railway in Russian literature: mythological origins. Rocznik Instytutu Polsko-Rosyjskiego, 1, 41-56.

Kosovsky, V.V. (1991). Living literature and creative dogmas. To the controversy about socialist realism. Social Sciences and Modernity, 4, 44-59.

Leontieva, K.N. (2007). East, Russia and Slavism. Moscow: Eksmo.

Lesovichenko, A.M, Maltseva, E.A. (2014). The mother archetype as the basis of railway images in literature and art. World of Science, Culture, Education, 5, 48, 275-278.

Lotman, Yu.M. (2015). Semiotics of cinema and problems of cinema aesthetics. Moscow: Readli.

Makarevich, A. (2020). Carriage disputes. Retrieved from https://teksty-pesenok.ru/rus-andrejmakarevich/tekst-pesni-vagonnye-spory/1737770/

Makarov, V. (2020). The last train. Retrieved from https://teksty-pesenok.ru/rus-v-makarov/tekst-pesniposlednyaya-elektrichka/1758181/

Megaeva, K.I. (2002). F.M. Dostoevsky and L.N. Tolstoy (novels of the 6o-70s). Makhachkala: Publishing House "Dagestan". 
Nekrasov, N.A. (2015). Poems. Moscow: Children's Literature.

Nepomnyashikh, N.A. (2012). The railway as a complex of motives in Russian lyrics and epics, In: Plot-Motive Complexes of Russian Literature. Novosibirsk: Academic publishing house "Geo". 92-106.

Ostrovsky, A.N. (2016). Thunderstorm and other plays. Moscow: Azbuka.

Propp, V.Ya. (2014). The historical roots of the fairy tale. Moscow: Labirint.

Shchepanovskaya, E.M. (2012). The archetypes of death in world mythology and their modern spread. Retrieved from http://studydoc.ru/doc/3840012/shhepanovskaya-e.m.-arhetipy-smerti-v-mirovojmifologii-i-ih

Tolstoy, L.N. (2012). Kreutzer Sonata. Moscow: Ripol Klassika.

Tolstoy, L.N. (2013). Anna Karenina. Moscow: Azbuka.

Zemskova, D.D. (2016). Soviet production novel: evolution and artistic features of the genre. Moscow: M.V. Lomonosov Moscow State University. 